\title{
Short communication: Arcobacter butzleri and Arcobacter cryaerophilus survival and growth in artisanal and industrial ricotta cheese
}

\author{
F. Giacometti, ${ }^{* 1}$ M. N. Losio, † P. Daminelli,† E. Cosciani-Cunico, † E. Dalzini, $†$ and A. Serraino* \\ *Department of Veterinary Medical Sciences, University of Bologna, Ozzano Emilia, 40064 Bologna, Italy \\ †Experimental Institute for Zooprophylaxis in Lombardy and Emilia Romagna, 25124 Brescia, Italy
}

\begin{abstract}
Ricotta cheese is a ready-to-eat product with properties $\left(\mathrm{pH}>6.0, \mathrm{a}_{\mathrm{w}}>0.98-0.99\right)$ and moisture content (75-80\%) that may pose a risk to public health due to postprocess contamination by several bacterial pathogens, including Arcobacters. The objective of the study was to evaluate the behavior of Arcobacter butzleri and Arcobacter cryaerophilus in ricotta cheese during its shelf life assuming postprocessing contamination. Two types of ricotta cheese, artisanal water buffalo (WB) and industrial cow milk ricotta cheese, were experimentally contaminated with A. butzleri and A. cryaerophilus and the count was monitored at 2 different temperatures $\left(6^{\circ} \mathrm{C}\right.$ and $\left.12^{\circ} \mathrm{C}\right)$ during shelf life of $5 \mathrm{~d}$ for WB cheese and $22 \mathrm{~d}$ for industrial ricotta cheese. In WB ricotta cheese the A. butzleri count remained stable during the $5 \mathrm{~d}$ of storage at $6^{\circ} \mathrm{C}$, whereas a moderate but significant decrease was observed in A. cryaerophilus count. The counts of both species increased when WB ricotta cheese was stored at $12^{\circ} \mathrm{C}$. In industrial ricotta cheese stored at $6^{\circ} \mathrm{C}$, a significant reduction was observed both in A. butzleri and A. cryaerophilus counts during the 22 -d storage period; at $12^{\circ} \mathrm{C}$ storage, a count increase was observed for both Arcobacter species up to d 14 of storage after which the $\log \mathrm{cfu} / \mathrm{g}$ count resulted constant until d 22 of storage. The ability of A. butzleri and A. cryaerophilus to survive at $6^{\circ} \mathrm{C}$ and to grow at $12^{\circ} \mathrm{C}$ in ricotta cheese has significant food safety implications.

Key words: Arcobacter butzleri, Arcobacter cryaerophilus, ricotta cheese, survival, growth
\end{abstract}

\section{Short Communication}

Arcobacter species have a widespread distribution with a broad range of animal hosts, food, and environmental reservoirs, and are increasingly associated with human illness (Douidah et al., 2014). Some Arcobacter species are considered emerging enteropathogens and

Received March 11, 2015.

Accepted June 17, 2015

${ }^{1}$ Corresponding author: federica.giacometti3@unibo.it potential zoonotic agents (Collado and Figueras, 2011). In particular, the species A. butzleri and A. cryaerophilus have been reported to infect humans. A recent study found that members of the Arcobacter genus were the fourth most common pathogenic group (after Campylobacter spp., Salmonella spp. and toxigenic Clostridium difficile) isolated from fecal samples from persons with acute enteric disease (Van den Abeele et al., 2014).

In the dairy chain, Arcobacter spp. have been isolated from fecal samples of dairy animals (Wesley et al., 2000; Golla et al., 2002; Van Driessche et al., 2005; Vilar et al., 2010; Piva et al., 2013; Shah et al., 2013), in-line milk filters (Serraino et al., 2013b), and cow and water buffalo milk (Scullion et al., 2006; Milesi, 2010; Shah et al., 2012; Yesilmen et al., 2014). Raw or minimally processed foods are usually considered the main source of human Arcobacter infection in industrialized countries, and in food of animal origin, the initial source seems to be fecal contamination during the various stages of production (Ongör et al., 2004; Scullion et al., 2006, Van Driessche and Houf, 2008). However, Arcobacter contamination of food processing surfaces has been reported in poultry slaughterhouses, spinach processing plants, and dairy plants (Houf et al., 2002, 2003; Gude et al., 2005; Son et al., 2006; Ferreira et al., 2013; Giacometti et al., 2013a,b; Hausdorf et al., 2013; Scarano et al., 2014; Serraino and Giacometti, 2014). Food processing surfaces were demonstrated to be a source of secondary contamination even for strongly processed foods, and A. butzleri was isolated in both artisanal and industrial ricotta cheese at retail (Giacometti et al., 2013a; Scarano et al., 2014). These aspects pose a risk for consumers because ricotta cheese is a ready-to-eat product that provides a substrate $[\mathrm{pH}$ $>6.0$, water activity $\left(\mathbf{a}_{\mathrm{w}}\right)$ of $0.98-0.99$, and moisture content at $75-80 \%$ ] that is not limiting for the survival and growth of many pathogenic bacteria.

The objective of this study was to evaluate the behavior of A. butzleri and A. cryaerophilus in ricotta cheese during its shelf life assuming postprocessing contamination, to establish whether ricotta cheese can support the growth of these microorganisms. Two types of ricotta cheese, artisanal water buffalo (WB) and industrial 
cow milk ricotta cheese, were used for the experimental inoculation and the behavior of the A. butzleri and $A$. cryaerophilus populations was monitored at 2 different temperature conditions $\left(6^{\circ} \mathrm{C}\right.$ and $\left.12^{\circ} \mathrm{C}\right)$.

The artisanal WB ricotta cheese was produced in the cheese factory of the Department of Veterinary Medical Sciences, Bologna, Italy: about $10 \mathrm{~kg}$ of ricotta cheese was collected by sterilized tools and immediately transported to the laboratory; the industrial ricotta cheese was received from a local industry; ten $1.5-\mathrm{kg}$ packs of industrial cow ricotta cheese were transported to the laboratory. Both types of ricotta cheese were divided in 18 batches of $500 \mathrm{~g}$ each and used for the experimental inoculation on the same day of production for WB ricotta cheese and on the day after production for industrial cow ricotta cheese. The shelf life declared by manufacturers was 5 and $22 \mathrm{~d}$, respectively, for WB artisanal and industrial cow milk ricotta cheese at storage conditions of $6^{\circ} \mathrm{C}$.

For the inocula, one reference strain (A. butzleri strain DSM $8739^{\mathrm{T}}$ and A. cryaerophilus strain DSM $7289^{\mathrm{T}}$, Leibniz Institute DSMZ, Braunschweig, Germany) and 2 field isolates, respectively 2 A. butzleri (AB-61 and AB-83), isolated from dairy processing surfaces and from cheese (ricotta draining table and artisanal water buffalo ricotta cheese) in an artisanal dairy plant, and 2 A. cryaerophilus (AC-1 and AC-G29), isolated from WB feces and from processing surfaces (curd-cutting facilities) in an industrial dairy plant, were used in the study. Each strain was grown separately on nutrient agar supplemented with $5 \%$ laked horse blood (Oxoid, Basingstoke, UK) incubated at $30^{\circ} \mathrm{C}$ for 48 $\mathrm{h}$ microaerobically by evacuating $80 \%$ of the normal atmosphere and introducing a gas mixture of $8 \% \mathrm{CO}_{2}$, $8 \% \mathrm{H}_{2}$, and $84 \% \mathrm{~N}_{2}$ into the jar. Colonies present in the plates were collected by a sterile swab and suspended separately in saline ( $\mathrm{NaCl} 0.85 \%$, VWR International, Milan, Italy). The suspensions obtained were cultured separately in $1 \mathrm{~L}$ of Arcobacter broth (Oxoid) incubated in continuous agitation at $30^{\circ} \mathrm{C}$ for $48 \mathrm{~h}$ aerobically, then centrifuged at $3,000 \times g$ for $1 \mathrm{~h}$; the pellets were resuspended separately in $1 \mathrm{~L}$ of saline $(\mathrm{NaCl} 0.85 \%$, VWR International). For the bacterial inocula, the 3 suspensions of both A. butzleri and A. cryaerophilus strains were quantified spectrophotometrically (600 $\mathrm{nm}$ ), and diluted in Butterfield's phosphate buffer to obtain approximately the same concentration of each strain $\left(\mathrm{OD}_{600}=0.665 \pm 0.02,0.044 \pm 0.03\right.$, and 0.184 \pm 0.02 , respectively, for $A$. butzleri inoculated in cow industrial ricotta cheese at $6^{\circ} \mathrm{C}, A$. butzleri in other tests and A. cryaerophilus inocula). For each bacterial species, an equal volume of the 3 suspensions was pooled and the mix was used to inoculate ricotta cheese ( $5 \mathrm{~mL}$ of suspension was inoculated in $500 \mathrm{~g}$ of ricotta cheese and manually mixed with a sterile spoon) to obtain a final concentration in ricotta cheese of about $10^{4}$ to $10^{6} \mathrm{cfu} / \mathrm{g}$. The number of viable cells of the mix suspensions was verified by 10 -fold dilution and direct plating on nutrient agar supplemented with $5 \%$ laked horse blood (Oxoid) incubated at $30^{\circ} \mathrm{C}$ for $48 \mathrm{~h}$ microaerobically.

For each ricotta cheese type, the eighteen 500-g batches were used as follows: 6 batches were inoculated with A. butzleri ( 3 batches were stored at $6^{\circ} \mathrm{C}$ and 3 batches at $\left.12^{\circ} \mathrm{C}\right) ; 6$ batches were inoculated with $A$. cryaerophilus $\left(3\right.$ batches were stored at $6^{\circ} \mathrm{C}$ and 3 batches at $\left.12^{\circ} \mathrm{C}\right) ; 6$ batches were not inoculated and used as control $\left(3\right.$ batches were stored at $6^{\circ} \mathrm{C}$ and 3 batches at $12^{\circ} \mathrm{C}$ ). Storage conditions at $6^{\circ} \mathrm{C}$ and $12^{\circ} \mathrm{C}$ were selected to simulate conditions of optimal storage and thermal abuse at home throughout the shelf life claimed by each producer; the ricotta cheese batches were stored into 2 refrigerated incubators ClimasLab CIR 400 and the temperature was measured by a Thermo Button 22L data logger (Astori Tecnica s.n.c.). In addition, for each trial (2 types of ricotta cheese $\times$ 3 batches $\times 2$ incubation temperatures) a control was performed by inoculating the same concentration of the 2 Arcobacter species into $200 \mathrm{~mL}$ of brain heart infusion (BHI) broth (Oxoid).

From each type of ricotta cheese, 3 samples were collected before the Arcobacter experimental inoculation to verify the absence of natural Arcobacter spp. contamination by enrichment procedure, as described by Houf et al. (2001). Briefly, $25 \mathrm{~g}$ of sample was inoculated into $225 \mathrm{~mL}$ of Arcobacter broth (Oxoid) supplemented with $5 \%$ laked horse blood (Oxoid) and a mix of cefoperazone $(16 \mathrm{mg} / \mathrm{L})$, amphotericin B $(10 \mathrm{mg} / \mathrm{L})$, 5 -fluoruracil $(100 \mathrm{mg} / \mathrm{L})$, novobiocin $(32 \mathrm{mg} / \mathrm{L})$, and trimethoprim $(64 \mathrm{mg} / \mathrm{L})$ as a selective supplement. All antimicrobial substances were obtained as laboratory standard powders from Sigma (St. Louis, MO). After $48 \mathrm{~h}$ of incubation, an aliquot of $10 \mu \mathrm{L}$ of the enrichment broth was streaked onto selective Arcobacter agar plates prepared by suspending $24 \mathrm{~g} / \mathrm{L}$ of Arcobacter broth (Oxoid) and $12 \mathrm{~g} / \mathrm{L}$ of Agar Technical No. 3 (Oxoid) and supplemented with selective supplement as described above. The plates were incubated at 30 $\pm 1^{\circ} \mathrm{C}$ under microaerobic conditions and after $48 \mathrm{~h}$ of incubation were checked daily up to $5 \mathrm{~d}$.

From each inoculated batch, at each day of storage for WB artisanal ricotta cheese (from 0 to 5 ) and at d 0,1 , $2,3,7,10,14,17$, and 22 for industrial cow milk ricotta cheese, one samples of $10 \mathrm{~g}$ was collected to count, in duplicate, respectively, A. butzleri and A. cryaerophilus, by direct plating of serial decimal dilutions onto selective Arcobacter agar plates prepared as described above and incubated at $30 \pm 1^{\circ} \mathrm{C}$ under microaerobic 
Table 1. Evolution of Arcobacter butzleri (log cfu/g), lactic acid bacteria (LAB) count (log cfu/g), and pH during storage of water buffalo artisanal ricotta cheese stored at $6^{\circ} \mathrm{C}$ and $12^{\circ} \mathrm{C}^{1}$

\begin{tabular}{|c|c|c|c|c|c|c|}
\hline \multirow[b]{2}{*}{ Day } & \multicolumn{3}{|c|}{ Storage at $6^{\circ} \mathrm{C}$} & \multicolumn{3}{|c|}{ Storage at $12^{\circ} \mathrm{C}$} \\
\hline & A. butzleri & $\mathrm{pH}$ & LAB & A. butzleri & $\mathrm{pH}$ & LAB \\
\hline 1 & $4.65 \pm 0.10$ & $6.23 \pm 0.04$ & $<30(\mathrm{cfu} / \mathrm{g})$ & $5.82 \pm 1.00$ & $6.21 \pm 0.02$ & $3.46 \pm 0.44$ \\
\hline 2 & $4.61 \pm 0.18$ & $6.20 \pm 0.03$ & $<30(\mathrm{cfu} / \mathrm{g})$ & $6.15 \pm 0.26^{*}$ & $6.19 \pm 0.04$ & $4.54 \pm 1.47^{*}$ \\
\hline 3 & $4.71 \pm 0.28$ & $6.23 \pm 0.04$ & $<30(\mathrm{cfu} / \mathrm{g})$ & $7.18 \pm 0.15^{*}$ & $6.15 \pm 0.05$ & $6.59 \pm 2.07^{*}$ \\
\hline 4 & $4.68 \pm 0.11$ & $6.24 \pm 0.04$ & $<30(\mathrm{cfu} / \mathrm{g})$ & $7.46 \pm 0.12^{*}$ & $5.70 \pm 0.27$ & $8.25 \pm 1.27^{*}$ \\
\hline
\end{tabular}

${ }^{1}$ Data represent means of 3 batches.

*A significant difference was observed in the evolution of the bacterial population during study in relation to time 0 .

conditions for $72 \mathrm{~h}$. Colonies were counted and a selection of 10 colonies for each plate were subcultured and examined for presumptive identification such as growth under aerobic condition and cellular morphology. The DNA of at least 5 colonies from each plate was extracted using the REDExtract-N-Amp Tissue PCR Kit (Sigma) and subjected to species confirmation by multiplex PCR (Douidah et al., 2010).

From noninoculated batches, 3 samples were collected throughout storage (same sampling times) and analyzed by the enrichment procedure as described above to check the absence of Arcobacter spp.

The count from inoculated BHI broths was performed in parallel (same sampling times) and with the same procedure described for ricotta cheeses.

The following analyses were additionally performed in single on each sample for each batch: mesophilic lactic acid bacteria (LAB) count by 10-fold dilution and inclusion in M17 and MRS agar plates (Oxoid) incubated aerobically and under microaerobic conditions, respectively, at $35^{\circ} \mathrm{C}$ for $48 \mathrm{~h}$; $\mathrm{pH}$ values were measured by an instrument with automatic temperature compensation (Hanna Instruments HI 223, Milan, Italy); $a_{w}$ was determined by AquaLab model series 3 .

The A. butzleri and A. cryaerophilus counts and the $\mathrm{pH}$ and $\mathrm{a}_{\mathrm{w}}$ measurements at different time of storage were analyzed by repeated measures ANOVA; PRISM
5.0 software was used. Statistical significance was set at $P<0.05$.

The results of the study show that no Arcobacter spp. were detected in samples of ricotta cheese analyzed before inoculation or in any of the samples performed in noninoculated batches during the study. Values of $\mathrm{pH}$, $a_{w}$, and LAB count showed no significant differences between noninoculated batches and batches inoculated with $A$. butzleri and A. cryaerophilus in WB artisanal or in industrial ricotta cheeses. The $\mathrm{a}_{\mathrm{w}}$ observed values resulted unchanged until the end of the shelf life in the range 0.994 to 0.998 for $\mathrm{a}_{\mathrm{w}}$; $\mathrm{pH}$ values resulted substantially unchanged in WB ricotta cheese stored for $5 \mathrm{~d}$ at $6^{\circ} \mathrm{C}$ but showed a significant decrease in WB ricotta cheese stored at $12^{\circ} \mathrm{C}$ for $5 \mathrm{~d}$ (from $6.12 \pm 0.02$ to 5.21 \pm 0.34 ) and in industrial cow ricotta cheese both stored at $6^{\circ} \mathrm{C}$ and at $12^{\circ} \mathrm{C}$ (from $6.46 \pm 0.01$ to $5.88 \pm 0.05$ and from $6.47 \pm 0.00$ to $5.59 \pm 0.03$, respectively) for $22 \mathrm{~d}$. The LAB population was always $<30 \mathrm{cfu} / \mathrm{g}$ in industrial cow milk both in ricotta cheese stored at 6 and $12^{\circ} \mathrm{C}$ as well as in WB artisanal ricotta cheese at $6^{\circ} \mathrm{C}$ until d 5 of storage in which they increased to 2.02 $\log \mathrm{cfu} / \mathrm{g}$, whereas at $12^{\circ} \mathrm{C} \mathrm{LAB}$ increased to $9.32 \mathrm{log}$ $\mathrm{cfu} / \mathrm{g}$ (Tables 1, 2, 3, and 4) at the end of $5 \mathrm{~d}$ of storage.

In WB artisanal ricotta cheese, the $A$. butzleri count remained stable during the $5 \mathrm{~d}$ of storage at $6^{\circ} \mathrm{C}$ (Table $1)$, whereas a moderate but significant $(P=0.0068)$ de-

Table 2. Evolution of Arcobacter cryaerophilus (log cfu/g), lactic acid bacteria (LAB) count (log cfu/g), and pH during storage of water buffalo artisanal ricotta cheese stored at $6^{\circ} \mathrm{C}$ and $12^{\circ} \mathrm{C}^{1}$

\begin{tabular}{|c|c|c|c|c|c|c|}
\hline \multirow[b]{2}{*}{ Day } & \multicolumn{3}{|c|}{ Storage at $6^{\circ} \mathrm{C}$} & \multicolumn{3}{|c|}{ Storage at $12^{\circ} \mathrm{C}$} \\
\hline & A. cryaerophilus & $\mathrm{pH}$ & LAB & A. cryaerophilus & $\mathrm{pH}$ & $\mathrm{LAB}$ \\
\hline 1 & $5.40 \pm 0.05$ & $6.24 \pm 0.04$ & $<30(\mathrm{cfu} / \mathrm{g})$ & $5.90 \pm 0.39^{*}$ & $6.21 \pm 0.02$ & $3.45 \pm 0.43$ \\
\hline 2 & $5.30 \pm 0.5$ & $6.20 \pm 0.02$ & $<30(\mathrm{cfu} / \mathrm{g})$ & $6.94 \pm 0.58^{*}$ & $6.18 \pm 0.03$ & $4.44 \pm 1.07^{*}$ \\
\hline 3 & $5.24 \pm 0.02$ & $6.21 \pm 0.04$ & $<30(\mathrm{cfu} / \mathrm{g})$ & $7.56 \pm 0.19^{*}$ & $6.14 \pm 0.04$ & $6.58 \pm 1.27^{*}$ \\
\hline 4 & $5.19 \pm 0.04^{*}$ & $6.23 \pm 0.03$ & $<30(\mathrm{cfu} / \mathrm{g})$ & $7.72 \pm 0.19^{*}$ & $5.69 \pm 0.27$ & $8.20 \pm 1.70^{*}$ \\
\hline
\end{tabular}

${ }^{1}$ Data represent means of 3 batches.

*A significant difference was observed in the evolution of the bacterial population during study in relation to time 0 . 
Table 3. Evolution of Arcobacter butzleri (log cfu/g), lactic acid bacteria (LAB) count (log cfu/g), and $\mathrm{pH}$ during storage of cow industrial ricotta cheese stored at $6^{\circ} \mathrm{C}$ and $12^{\circ} \mathrm{C}^{1}$

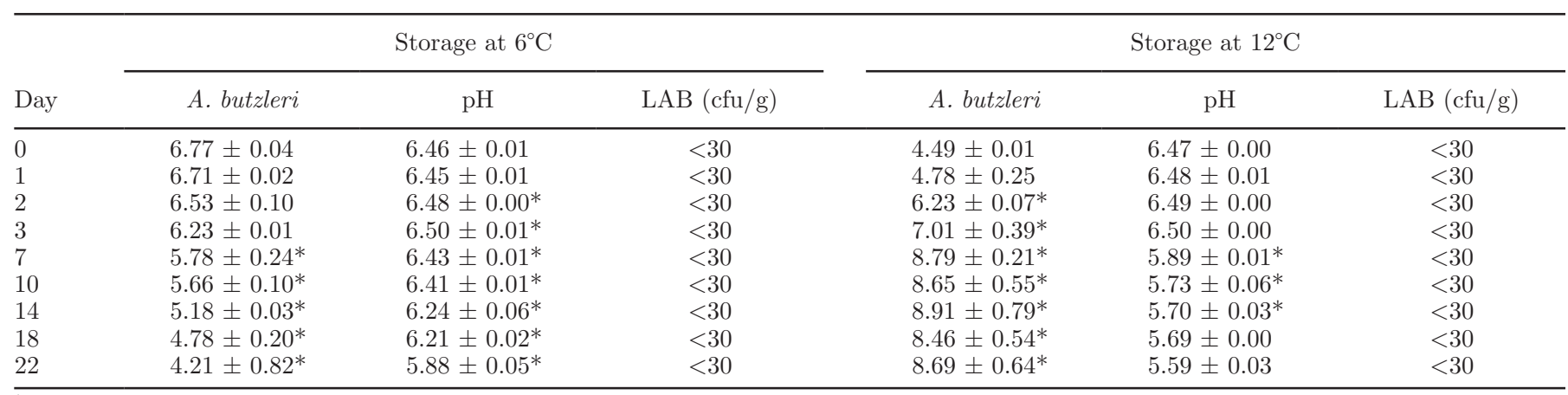

${ }^{1}$ Data represent means of 3 batches.

*A significant difference was observed in the evolution of the bacterial population during study in relation to time 0 .

crease was observed in A. cryaerophilus count (between 0 vs. 4 and 0 vs. $5 \mathrm{~d}$ of storage). An increase was shown in the count of both species when WB ricotta cheese was stored at $12^{\circ} \mathrm{C}$, from $4.27 \pm 0.13 \log \mathrm{cfu} / \mathrm{g}$ to $8.03 \pm$ 0.26 , and from $5.15 \pm 0.04 \log \mathrm{cfu} / \mathrm{g}$ to $8.34 \pm 0.14$ for A. butzleri and A. cryaerophilus, respectively (Tables 1 and 2). Values of $\mathrm{pH}$ showed a moderate increase during the storage period at $6^{\circ} \mathrm{C}$ and a significant decrease from d 4 of storage in WB ricotta cheeses stored at $12^{\circ} \mathrm{C}$ to a value of 5.21 at the end of the 5 -d period (see Tables 1 and 2). The LAB count, starting from a value of $<30 \mathrm{cfu} / \mathrm{g}$ at d 0 was unchanged at $6^{\circ} \mathrm{C}$ until d 4 of storage followed by an increase on d 5 (Tables 1 and 2 ). In $\mathrm{WB}$ ricotta cheese stored at $12^{\circ} \mathrm{C}$, a significant increase in the LAB count was observed during the period at d 5 of storage (Tables 1 and 2).

In industrial ricotta cheese stored at $6^{\circ} \mathrm{C}$, a significant reduction was observed both in $A$. butzleri and A. cryaerophilus count during the $22-\mathrm{d}$ storage period (Tables 3 and 4 ); by contrast, at $12^{\circ} \mathrm{C}$, a significant count increase was observed for both Arcobacter species up to d 14 of storage (4.42 and $3.44 \mathrm{log}$ cfu/g increase for A. butzleri and A. cryaerophilus, respectively) after which the log cfu/g count slightly decreased until d 22 of storage (see Tables 3 and 4). A significant decrease in the $\mathrm{pH}$ value was observed in both ricotta cheeses stored at $6^{\circ} \mathrm{C}$ and at $12^{\circ} \mathrm{C}$ from $\mathrm{d} 7$ of storage as reported in Tables 3 and 4 . The LAB count was $<30$ $\mathrm{cfu} / \mathrm{g}$ until the end of the storage time (Tables 3 and 4).

In BHI broth, A. butzleri demonstrated the ability to replicate at $12^{\circ} \mathrm{C}$ and $A$. cryaerophilus count increased at both $\left(6^{\circ} \mathrm{C}\right.$ and $\left.12^{\circ} \mathrm{C}\right)$ of the incubation temperatures chosen (data not shown).

The present study is the first to investigate the behavior of $A$. butzleri and A. cryaerophilus in ricotta cheese. The results clearly show that ricotta cheese is able to support the growth of these Arcobacter species in case of moderate thermal abuse $\left(12^{\circ} \mathrm{C}\right)$ and that both the investigated species are able to survive during the shelf life of 2 different types of ricotta cheese when stored at refrigeration temperature (up to $22 \mathrm{~d}$ at $6^{\circ} \mathrm{C}$ ).

The $\mathrm{a}_{\mathrm{w}}$ and $\mathrm{pH}$ were not limiting to Arcobacter growth or survival; in fact the $\mathrm{a}_{\mathrm{w}}$ values were in the range of 0.994 to 0.998 for all the period of the storage

Table 4. Evolution of Arcobacter cryaerophilus (log cfu/g), lactic acid bacteria (LAB) count (cfu/g), and pH during storage of cow industrial ricotta cheese stored at $6^{\circ} \mathrm{C}$ and $12^{\circ} \mathrm{C}^{1}$

\begin{tabular}{|c|c|c|c|c|c|c|}
\hline Day & \multicolumn{3}{|c|}{ Storage at $6^{\circ} \mathrm{C}$} & \multicolumn{3}{|c|}{ Storage at $12^{\circ} \mathrm{C}$} \\
\hline 2 & $5.09 \pm 0.24$ & $6.48 \pm 0.00^{*}$ & $<30$ & $6.81 \pm 0.27^{*}$ & $6.49 \pm 0.01$ & $<30$ \\
\hline 3 & $5.13 \pm 0.23$ & $6.51 \pm 0.01^{*}$ & $<30$ & $7.82 \pm 0.39^{*}$ & $6.50 \pm 0.00$ & $<30$ \\
\hline 7 & $4.64 \pm 0.29^{*}$ & $6.44 \pm 0.01^{*}$ & $<30$ & $8.46 \pm 0.51^{*}$ & $5.90 \pm 0.01^{*}$ & $<30$ \\
\hline 18 & $3.55 \pm 0.07^{*}$ & $6.20 \pm 0.00^{*}$ & $<30$ & $8.34 \pm 0.20^{*}$ & $5.70 \pm 0.01$ & $<30$ \\
\hline 22 & $4.10 \pm 0.36^{*}$ & $5.90 \pm 0.02^{*}$ & $<30$ & $8.06 \pm 0.85^{*}$ & $5.60 \pm 0.03$ & $<30$ \\
\hline
\end{tabular}

${ }^{1}$ Data represent means of 3 batches.

*A significant difference was observed in the evolution of the bacterial population during study in relation to time 0 . 
that is over the reported minimal $\mathrm{a}_{\mathrm{w}}(0.985$ to 0.990$)$ for Arcobacter growth (Cervenka, 2007). The $\mathrm{pH}$ values remained in the reported optimal $\mathrm{pH}$ range (6.0 to 8.0; Lehner et al., 2005) for most of the study and in industrial ricotta cheese they never reached the lower $\mathrm{pH}$ growth (5.0 to 5.5) reported for Arcobacter (Hilton et al., 2001; D'Sa and Harrison, 2005; see Tables 3 and 4). In artisanal $\mathrm{WB}$ ricotta cheese, the $\mathrm{pH}$ reached a value of 5.21 only at $\mathrm{d} 5$ of storage at $12^{\circ} \mathrm{C}$.

Arcobacter butzleri count remained stable in artisanal WB ricotta cheese but decreased in industrial ricotta cheese when stored at $6^{\circ} \mathrm{C}$ (see Tables 1 and 3). A progressive decrease of the log cfu count was in agreement with several reports in culture media (Hilton et al., 2001; Kjeldgaard et al., 2009), water with or without organic material (Van Driessche and Houf, 2008), and milk (Giacometti et al., 2014) stored at refrigeration temperatures. Given that the same strains and the same storage conditions were used in the 2 experiments, the apparent variables between the 2 tests could be attributed to the different type of cheeses used in terms of composition (water buffalo vs. cow milk ricotta cheese) or in terms of natural contaminant microflora (artisanal vs. industrial production system); both the composition of the medium (Kjeldgaard et al., 2009) and the presence of natural microflora (Balamurugan et al., 2013) were demonstrated to influence the growth and survival of A. butzleri in foods. In particular, Balamurugan et al. (2013) demonstrated that natural contaminant microflora may enhance A. butzleri survival on vacuum-packaged beef and speculated that the enhanced survival could be attributed to the scavenging of oxygen passing through bag barrier (that can be excluded in the present study) or to the production of metabolites by the natural microflora. In addition, the reported decrease in cow industrial ricotta cheese, in comparison with WB artisanal ricotta cheese, could be due to the longer time ( 22 vs. $5 \mathrm{~d}$ ) the microorganisms are under unfavorable temperature conditions and a similar trend could be observed in WB artisanal ricotta cheese if the test could be extended for a longer time.

Arcobacter cryaerophilus log cfu count decreased in the 2 types of ricotta cheese when stored at $6^{\circ} \mathrm{C}$. The reported minimal growth temperature of $A$. cryaerophilus is $5^{\circ} \mathrm{C}$ (Neill et al., 1985), but the decrease observed in this study reflects a similar behavior in milk at 10 and $4^{\circ} \mathrm{C}$ (Giacometti et al., 2014).

When the ricotta cheeses were stored at $12^{\circ} \mathrm{C}$ a significant increase in both $A$. butzleri and A. cryaerophilus count was observed during the $5 \mathrm{~d}$ of storage in WB ricotta cheese (up to 8.03 and $8.34 \mathrm{log} \mathrm{cfu} / \mathrm{g}$, respectively, for A. butzleri and A. cryaerophilus) and in cow milk ricotta cheese during the $22 \mathrm{~d}$ of storage (up to
8.69 and $8.06 \log \mathrm{cfu} / \mathrm{g}$, respectively, for A. butzleri and A. cryaerophilus). Kjeldgaard et al. (2009) reported the minimum growth temperature for A. butzleri on chicken meat juice medium and $\mathrm{BHI}$ at $10^{\circ} \mathrm{C}$. By contrast, both A. butzleri and A. cryaerophilus were unable to grow in milk at $10^{\circ} \mathrm{C}$ (Giacometti et al., 2014). The higher incubation temperature applied in the present study $\left(12^{\circ} \mathrm{C}\right.$ vs. $\left.10^{\circ} \mathrm{C}\right)$ and the different type of food tested may have influenced the results.

The ability of $A$. butzleri to survive during the shelf life of dairy produce in both cases of thermal abuse and optimal storage temperature was previously reported, but growth was observed only in the case of severe thermal abuse (Serraino et al., 2013a; Giacometti et al., 2014); the isolation of $A$. butzleri in ricotta cheeses sampled at retail and the ability of $A$. butzleri and $A$. cryaerophilus to grow at $12^{\circ} \mathrm{C}$ [i.e., roughly the temperature of home storage (Beaufort et al., 2008)] can have food safety implications because ricotta cheese is a ready-to-eat product. In addition, the increase in Arcobacter spp. count in inoculated batches occurred without significant changes in organoleptic properties and $\mathrm{pH}$ in comparison with noninoculated batches. This finding must also be taken into account because the consumer may have no indication of the multiplication of potential pathogenic bacteria in the cheese.

The findings of this study should help to draw more attention to A. butzleri and A. cryaerophilus in dairy plants, and in the food processing environment in general, and to their importance as human pathogens entering the food chains. Due to the few reports available in literature, future studies should address the retail prevalence of dairy products contaminated by Arcobacter spp. for the development of a proper risk assessment.

\section{ACKNOWLEDGMENTS}

Study was funded under program "TERRAVITA: Biodiversità, territorio e nutrizione. La sostenibilità dell'agro-alimentare italiano."

\section{REFERENCES}

Balamurugan, S., A. Rafath, and J. R. Chambers. 2013. Survival of Arcobacter butzleri on vacuum packaged chill stored beef. Food Res. Int. 52:503-507.

Beaufort, A., M. Cornu, H. Bergis, and A. L. Lardeux. 2008. Technical guidance document on shelf-life studies for Listeria monocytogenes in ready-to-eat foods. Agence Française de Sécurité Sanitarie des Aliments, Maisons-Alfort, France.

Cervenka, L. 2007. Survival and inactivation of Arcobacter spp., a current status and future prospects. Crit. Rev. Microbiol. 33:101-108.

Collado, L., and M. J. Figueras. 2011. Taxonomy, epidemiology, and clinical relevance of the genus Arcobacter. Clin. Microbiol. Rev. 24:174-192. 
D'Sa, E. M., and M. A. Harrison. 2005. Effect of pH, NaCl content, and temperature on growth and survival of Arcobacter spp. J. Food Prot. 68:18-25.

Douidah, L., L. De Zutter, J. Baré, and K. Houf. 2014. Towards a typing strategy for Arcobacter species isolated from humans and animals and assessment of the in vitro genomic stability. Foodborne Pathog. Dis. 11:272-280.

Douidah, L., L. De Zutter, P. Vandamme, and K. Houf. 2010. Identification of five human and mammal associated Arcobacter species by a novel multiplex-PCR assay. J. Microbiol. Methods 80:281-286.

Ferreira, S., M. J. Fraqueza, J. A. Queiroz, F. C. Domingues, and M. Oleastro. 2013. Genetic diversity, antibiotic resistance and biofilmforming ability of Arcobacter butzleri isolated from poultry and environment from a Portuguese slaughterhouse. Int. J. Food Microbiol. 162:82-88.

Giacometti, F., A. Lucchi, G. Manfreda, D. Florio, R. G. Zanoni, and A. Serraino. 2013a. Occurrence and genetic diversity of Arcobacter butzleri in an artisanal dairy plant in Italy. Appl. Environ. Microbiol. 79:6665-6669.

Giacometti, F., A. Serraino, G. Marchetti, E. Bonerba, D. Florio, E. Bonfante, D. Florio, E. Bonfante, R. G. Zanoni, and R. Rosmini. 2013b. Isolation of Arcobacter butzleri in environmental and food samples collected in industrial and artisanal dairy plants. Italian J. Food Safety 2:121-123.

Giacometti, F., A. Serraino, F. Pasquali, A. De Cesare, E. Bonerba, and R. Rosmini. 2014. Behavior of Arcobacter butzleri and Arcobacter cryaerophilus in ultrahigh-temperature, pasteurized, and raw cow's milk under different temperature conditions. Foodborne Pathog. Dis. 11:15-20.

Golla, S. C., E. A. Murano, L. G. Johnson, N. C. Tipton, E. A. Cureington, and J. W. Savell. 2002. Determination of the occurrence of Arcobacter butzleri in beef and dairy cattle from Texas by various isolation methods. J. Food Prot. 65:1849-1853.

Gude, A., T. J. Hillman, C. R. Helps, V. M. Allen, and J. E. L. Corry. 2005. Ecology of Arcobacter species in chicken rearing and processing. Lett. Appl. Microbiol. 41:82-87.

Hausdorf, L., M. Neumann, I. Bergmann, K. Sobiella, K. Mundt, A. Fröhling, O. Schlüter, and M. Klocke. 2013. Occurrence and genetic diversity of Arcobacter spp. in a spinach-processing plant and evaluation of two Arcobacter-specific quantitative PCR assays. Syst. Appl. Microbiol. 36:235-243.

Hilton, C. L., B. M. Mackey, A. J. Hargreaves, and S. J. Forsythe. 2001. The recovery of Arcobacter butzleri NCTC 12481 from various temperature treatments. J. Appl. Microbiol. 91:929-932.

Houf, K., L. De Zutter, J. Van Hoof, and P. Vandamme. 2002. Occurrence and distribution of Arcobacter species in poultry processing. J. Food Prot. 65:1233-1239.

Houf, K., L. De Zutter, B. Verbeke, J. Van Hoof, and P. Vandamme. 2003. Molecular characterization of Arcobacter isolates collected in a poultry slaughterhouse. J. Food Prot. 66:364-369.

Houf, K., L. A. Devriese, L. De Zutter, J. Van Hoof, and P. Vandamme. 2001. Development of a new protocol for the isolation and quantification of Arcobacter species from poultry products. Int. J. Food Microbiol. 71:189-196.

Kjeldgaard, J., K. Jørgensen, and H. Ingmer. 2009. Growth and survival at chiller temperatures of Arcobacter butzleri. Int. J. Food Microbiol. 131:256-259.

Lehner, A., T. Tasara, and R. Stephan. 2005. Relevant aspects of Arcobacter spp. as potential foodborne pathogen. Int. J. Food Microbiol. 102:127-135.

Milesi, S. 2010. Emerging pathogen Arcobacter spp. in food of animal origin. PhD Thesis, Doctoral Program in Animal Nutrition and Food Safety, University of Milan, Italy.
Neill, S. D., J. N. Campbell, J. J. O'Brien, S. T. C. Wetherup, and W. A. Ellis. 1985. Taxonomic position of Campylobacter cryaerophila sp. nov. Int. J. Syst. Bacteriol. 35:342-356.

Ongör, H., B. Cetinkaya, M. N. Açik, and H. I. Atabay. 2004. Investigation of arcobacters in meat and faecal samples of clinically healthy cattle in Turkey. Lett. Appl. Microbiol. 38:339-344.

Piva, S., A. Serraino, D. Florio, F. Giacometti, F. Pasquali, G. Manfreda, and R. G. Zanoni. 2013. Isolation of Arcobacter species in water buffaloes (Bubalus bubalis). Foodborne Pathog. Dis. 10:475477.

Scarano, C. F. Giacometti, G. Manfreda, A. Lucchi, E. Pes, C. Spanu, E. P. L. De Santis, and A. Serraino. 2014. Arcobacter butzleri in sheep ricotta cheese at retail and related sources of contamination at the industrial dairy plant. Appl. Environ. Microbiol. 80:70367041.

Scullion, R., C. S. Harrington, and R. H. Madden. 2006. Prevalence of Arcobacter spp. in raw milk and retail raw meats in Northern Ireland. J. Food Prot. 69:1986-1990.

Serraino, A., D. Florio, F. Giacometti, S. Piva, D. Mion, and R. G. Zanoni. 2013b. Presence of Campylobacter and Arcobacter species in in-line milk filters of farms authorized to produce and sell raw milk and of a water buffalo dairy farm in Italy. J. Dairy Sci. 96:2801-2807.

Serraino, A., and F. Giacometti. 2014. Occurrence of Arcobacter species in industrial dairy plants. J. Dairy Sci. 97:2061-2065.

Serraino, A., F. Giacometti, P. Daminelli, M. N. Losio, G. Finazzi, G. Marchetti, A. V. Zambrini, and R. Rosmini. 2013a. Survival of Arcobacter butzleri during production and storage of artisan water buffalo mozzarella cheese. Foodborne Pathog. Dis. 10:820-824.

Shah, A. H., A. A. Saleha, M. Murugaiyah, Z. Zunita, and A. A. Memon. 2012. Prevalence and distribution of Arcobacter spp. in raw milk and retail raw beef. J. Food Prot. 75:1474-1478.

Shah, A. H., A. A. Saleha, Z. Zunita, M. Murugaiyah, A. B. Aliyu, and N. Jafri. 2013. Prevalence, distribution and antibiotic resistance of emergent Arcobacter spp. from clinically healthy cattle and goats. Transbound. Emerg. Dis. 60:9-16.

Son, I., M. D. Englen, M. E. Berrang, P. J. Fedorka-Cray, and M. A. Harrison. 2006. Genetic diversity of Arcobacter and Campylobacter on broiler carcasses during processing. J. Food Prot. 69:1028-1033.

Van den Abeele, A. M., D. Vogelaers, J. Van Hende, and K. Houf. 2014. Prevalence of Arcobacter species among humans, Belgium, 2008-2013. Emerg. Infect. Dis. 20:1731-1734.

Van Driessche, E., and K. Houf. 2008. Survival capacity in water of Arcobacter species under different temperature conditions. J. Appl. Microbiol. 105:443-451.

Van Driessche, E., K. Houf, F. Vangroenweghe, L. De Zutter, and J. V. Hoof. 2005. Prevalence, enumeration and strain variation of Arcobacter species in the faeces of healthy cattle in Belgium. Vet. Microbiol. 105:149-154.

Vilar, M. J., F. J. Peña, I. Pérez, F. J. Diéguez, M. L. Sanjuán, J. L. Rodríguez-Otero, and E. Yus. 2010. Presence of Listeria, Arcobacter, and Campylobacter spp. in dairy farms in Spain. Berl. Munch. Tierarztl. Wochenschr. 123:58-62.

Wesley, I. V., S. J. Wells, K. M. Harmon, A. Green, L. SchroederTucker, M. Glover, and I. Siddique. 2000. Fecal shedding of Campylobacter and Arcobacter spp. in dairy cattle. Appl. Environ. Microbiol. 66:1994-2000.

Yesilmen, S., A. Vural, M. E. Erkan, and I. H. Yildirim. 2014. Prevalence and antimicrobial susceptibility of Arcobacter species in cow milk, water buffalo milk and fresh village cheese. Int. J. Food Microbiol. 188:11-14. 